\title{
Articles
}

\section{Embedded Librarianship is a Winning Proposition}

By Warren N. Jacobs

\section{Abstract}

A reference/instruction librarian used targeted outreach to furnish library services to faculty and students while assigned to work in the College of Education during a library renovation project. Due to the success of this temporary assignment, the author has subsequently maintained regular office hours in the College to provide research consultations for faculty and students, collaborate on collection development, and continue outreach efforts resulting in increased requests for research assistance and course-integrated information literacy instruction. The benefits and challenges of embedded librarianship in an academic department are also discussed.

\section{Introduction}

Due to the library's renovation project scheduled to begin in January, 2009, I needed to find a vacant office on campus in which to work for the duration of the project. I was uneasy about where I would work and what I would be able to accomplish outside the library during that period of time. The Dean of Library Services contacted his counterpart in the College of Education (COE). A vacant office was quickly found. I was about to begin an unexpectedly fruitful experience as an embedded librarian.

\section{Background}

During an extended strategic planning process in spring 2007, one of the ten goals identified by the library faculty was a desire to build a closer connection with the teaching faculty to help foster student success (-ibrary Strategic Plan," 2007).

The Dean had a long-standing interest in expanding the library's liaison program for collection development into a model providing library services and outreach within an academic department.

In 2009, nine faculty librarians served as liaison to 33 academic departments. The liaison works directly with a departmental faculty representative to facilitate additions to the collection in his/her assigned areas, as well as evaluating the collection. In recent years, ongoing budget problems in California have necessitated a reduction of the library's budget for collections. As a result, liaisons also work closely with departmental faculty, seeking guidance when periodical subscriptions and standing orders must be cancelled.

The academic departments are grouped into six Colleges containing as few as four and as many as fourteen disciplines (CSU Stanislaus, 2008b). The academic departments are not always located in the same physical space, making the College structure somewhat unwieldy. As a result, the Dean had not moved forward on his idea of embedding a librarian within a College.

The COE was perhaps the best candidate for a pilot project of embedding a librarian within an academic department since Teacher Education, Advanced Studies in Education, and Liberal Studies were located within close proximity and worked together frequently on various initiatives (CSU Stanislaus, 2008a; CSU Stanislaus, 2008b). Kinesiology (formerly Physical Education and Health) was located in the Field House across campus but also collaborated with the other departments in the College (CSU Stanislaus, 2008b).

\section{Literature Review}

Librarians can be embedded within a course, an academic department or college structure, or the university as a whole. Dewey (2005) defines 
embedding as a concept in which the one distinct group is integrated with another (p. 6). In order for librarians to provide services relevant to teaching, learning, and scholarship, collaboration with patrons is required. Đirect and purposeful interactions" with patrons enhances that collaboration (Dewey, 2005, p. 6). Shumaker's (2009) definition differs slightly, focusing on the placement of a reference librarian where the user is located to teach research skills whenever and wherever instruction is needed" (p. 239). By embedding a librarian in an academic department, the library benefits through heightened awareness of its resources and services (Shumaker, 2009, p. 239).

Libraries were not always separate entities on campuses. Libraries were located in academic departments before the size of the collections created a need for research libraries in which all collections could be collocated (Dewey, 2005, p. $6)$. The increasing technological changes that have taken place over the past few decades and the difficult budgetary constraints under which all libraries are operating have created further separation from the original model of departmental libraries.

In order to remain relevant, libraries are challenged with providing resources and services when and where they are needed by our users. The expectation that patrons will come to the library when they have an information need is an antiquated service model. Changes have already taken place to make our resources and services available $24 / 7$. One example is the provision of remote access to library catalogs and periodical databases to facilitate research.

Kesselman and Watstein (2009) argue that librarians must be embedded to fully support research and teaching (p. 385). In the academic environment, a librarian can be embedded into a face-to-face or an online course. Examples of embedding a librarian into a traditional course setting include participation in each class session of a freshman speech course (Hall, 2008, p. 29), and two librarians who were essential to the research and technological needs of a sociology course field trip to the South (Smith \& Sutton, 2008, p. 71).

The library can also have a presence in an online course taught through Blackboard or other course management software. Links to library class pages, bibliographies, and tutorials serve to embed the library into online courses (Bozeman \& Owens, 2008, p. 57; Dewey, 2005, p. 15; Drumm \& Havens, 2005, p. 25; Matthew \& Schroeder, 2006, p. 61; Ramsay \& Kinnie, 2006, p. 35).

Meeting the research needs of online students involves a balance between best practices and a student's need to successfully complete a specific assignment (Matthew \& Schroeder, 2006, p. 63). Stewart (2007) discusses examples that include the use of library tip sheets and a separate research discussion forum to provide assistance to online students at Pulaski Technical College (p. 29). Discussion forums by curricular area or disciplinespecific library courses can also meet research needs (Matthew \& Schroeder, 2006, p. 64). Despite our best efforts, questions can be slow in coming. Bozeman and Owens (2008) tell of the experience of turking" in a discussion forum waiting for research questions (p. 59).

Librarians may become embedded through the assumption of a campus leadership role. Dewey (2005) provides examples in which librarians can utilize their areas of expertise such as intellectual freedom, copyright, and scholarly communication to benefit the entire university through service on campus committees (p. 10).

Embedded librarianship is not limited solely to academic institutions. It is irrelevant whether an information professional works in an academic, public, government, business, medical, nonprofit organization, or other type of library. If you are furnishing information services outside of that library in proximity to a group that is primarily constituted of non-librarians, you are an embedded librarian (Kesselman \& Watstein, 2009, p. 386).

Among the best practices of embedded librarianship in an academic setting are departmental liaison models in which 
collaborations with a faculty representative are multi-dimensional rather than focusing solely on collection development (Dewey, 2005, p. 11; Glynn \& Wu, 2003, p. 123). The integration of information literacy into discipline-specific curriculum and the provision of research consultations for faculty and students are two of the best examples of collaboration (Dewey, 2005, p. 11). The most effective collaborations foster a closer relationship with teaching faculty because the library is focused on the faculty's needs (Shumaker, 2009, p. 240), and endeavors to understand and address the department's research and instructional desires (Dewey, 2005, p. 12). In many cases, patrons value the library's resources and services to the extent that the customer takes the initiative to foster an embedded relationship (Shumaker, 2009, p. 241).

The methods of communication with patrons should be chosen for their utmost effectiveness (Glynn \& Wu, 2003, p. 123). Glynn and Wu (2003) determined that personal contact, telephone calls, and e-mail messages are just a few of the ways that librarian liaisons can demonstrate a sincere interest in the scholarly activities of department faculty, as well as furnishing new services and materials (p. 123). In providing the services that our patrons need, we help them look good while at the same time establishing our own credibility as information professionals (Bartnik, 2007, p. 6; Shumaker, 2009, p. 240). The best way to facilitate good service is to work where the faculty are working (Bartnik, 2007, p. 6).

To increase the likelihood of success, it is important to assess the organization's readiness for change (Shumaker, 2009, p. 241). Workload will increase when an embedded librarian service model is successful (Bartnik, 2007, p. 5). Before embarking on change, organizations need to balance the workload of embedded librarians and the librarians who will be remaining in the library (Shumaker, 2009, p. 242). Before choosing to work outside of the library, information professionals need to revamp organizational charts that prevent libraries from seizing opportunities as they are presented (Kesselman \& Watstein, 2009, p. 397).

\section{Working in the College of Education}

Before leaving for my temporary quarters in the COE, I was instructed to facilitate the library services needed to support the new doctoral program in education. As I thought about that assignment, I realized that there was no need to stop with one program. I decided to use my time in the COE to make a concerted effort to reach as many faculty members as possible with a goal of increasing the utilization of the library's resources and services.

I began by sending out an e-mail announcement of my willingness to provide individual research consultations to faculty and students, collaborate on information literacy instruction, and facilitate additions to the library's collection in education. My message included links to library resources, and examples of class library Web pages that I had compiled (Eibrary Class Pages," n.d.). The e-mail message generated an immediate response. I was inundated with requests for assistance.

Each day, I spent many hours assisting professors in locating literature to support their teaching and scholarship, including the preparation of books, articles, grant and course proposals, and conference papers (Bartnik, 2007, p. 5). To foster a closer collaboration, I dropped by faculty members' offices and talked with them about the ways that the library could assist with teaching, research, and the retention of students. I made sure to pass out business cards. I facilitated requests for additions to the collection including researching the availability of reports and other scholarly materials online, and provided publisher catalogs to faculty.

Once the renovation project was complete, it was time for me to return to the library. I was encouraged about the success of my experience as an embedded librarian working outside of the library. A department chair and several professors expressed interest in an ongoing arrangement in which I would continue working in the College on a regular basis. The former Dean of Library Services had left for a position with another academic institution. I consulted with the Interim 
Director of Library Services and received his approval to continue working in the COE on a limited basis each week during the spring semester. My objective was to furnish research and instructional assistance to students and faculty who were unable to come to the library.

\section{Challenges and Opportunities}

While I was pleasantly surprised by the positive response that my work in the College of Education was receiving, there were challenges to continuing this service on a regular basis. Although there had been previous library faculty discussions about trying to embed a librarian within a College, the opportunity that was presented to try a new service model was not received as positively as I might have hoped. There was no interest by the library faculty in replicating this service model for other departments or Colleges on campus. My assignment was viewed as a pilot project, not a long-term commitment.

Despite assurances to the contrary, some colleagues expressed concern that working in the COE might prevent me from fulfilling my duties in the areas of reference and information literacy instruction. In anticipating my colleagues ${ }^{6}$ concerns over workload, I let them know that I planned to maintain the same number of scheduled reference desk hours and would be teaching course-integrated instructional sessions in the library so that other librarians would not be adversely affected (Bartnik, 2007, p. 7; Shumaker, 2009, p. 242).

I previously worked one night per week in the library in a rotation with other librarians. To fulfill my instructional responsibilities, I taught more course-integrated instructional sessions at night. As a result, I often began work before 8:00 a.m. and finished after 7:00 p.m. Through outreach efforts that included targeted e-mail messages to faculty teaching specific courses that contained a research component, I was able to increase my instructional sessions by $20 \%$ from 2008 . Of the 36 instructional sessions that I taught in 2009, $69 \%$ can be attributed to my presence in the college. The longer hours were well worth the effort.
Opportunities to be of service came from my proximity to the teaching faculty (Bartnik, 2007, p. 6). I was able to work more closely with the students and faculty in the areas of Educational Leadership, Educational Administration, and Kinesiology. These programs had not previously collaborated with the library on a regular basis. I also presented on the library's resources and services to support the Master's degree program in Curriculum and Instruction at a workshop for COE faculty.

I advertised my presence in the College of Education with posters, multiple e-mail and student listserv announcements, and announcements and handouts in the classes I taught. I attended three departmental faculty meetings to make brief announcements, answer questions about the library's resources and services for students and faculty, and pass out handouts. Each of these methods generated additional opportunities to serve students and faculty.

Initially I wasn't sure how much time to schedule in the COE. I allotted nine hours per week during the spring semester. I found that I was engaged in assisting students and faculty about half of the time that I spent in the COE each week. I used the extra time to compile class library Web pages that grouped relevant databases, catalogs, and Webbased resources with step-by-step instructions, making it easier for students to complete their course assignments (EDMS 4140,” 2009). The class pages were linked into the Blackboard course management system, ensuring a library presence in the specific course. I also prepared instructional materials in both print and electronic formats to share with faculty and students. Topics included American Psychological Association (APA) citation format, searching relevant databases, and the process to set up e-mail alerts for journal content.

Primarily due to the needs of the library, and to a lesser extent my desire to be engaged in assisting students and faculty a greater percentage of my time, I scheduled two days per week in the fall semester in which to hold office hours in the COE. 
While the actual number of hours worked each week in the $\mathrm{COE}$ declined from nine to four, the percentage of time spent in assisting faculty and students with research consultations increased from $50 \%$ to $75 \%$ of the hours worked in the COE.

During 2009, I furnished more than 150 research consultations in the COE. Each consultation averaged slightly less than an hour. Faculty consultations accounted for about $70 \%$ of the total, with student consultations accounting for the remaining $30 \%$. As a basis of comparison, the library faculty usually provides about 100 research appointments each year in addition to helping students at the reference desk. Reference statistics vary based on the hour of the day, day of the week, and academic term.

\section{Future Goals}

Due to the success of this experiment in embedded librarianship, I plan to continue scheduling office hours each week in the College of Education (Dewey, 2005, p. 12; Kesselman \& Watstein, 2009 , p. 390). Among my goals is continued outreach in an effort to increase the number of research consultations for students, as well as faculty. When I asked students how they were directed to my office, I was told that another student or a professor had given them my contact information. I found that faculty members also sent their colleagues to my office for assistance (Dewey, 2005, p. 12). While outreach to potential users is important, I've learned that satisfied faculty and students are the best advertisement for the library's resources and services.

I've asked COE faculty to consider embedding a librarian within a course taught in Blackboard (Matthew \& Schroeder, 2006, p. 61). I teach a research and information literacy credit course online in which I utilize discussion forums on ethical issues involving the use of information, and furnish online instruction through assigned readings, screencasts, podcasts, links to Web pages, and other curriculum materials. While unsuccessful in my first attempts to integrate a librarian within a discipline-specific online course, I will continue my efforts to provide assistance to distant learners (Bozeman \& Owens, 2008, p. 57; Matthew \& Schroeder, 2006, pp. 62-63; Stewart, 2007, pp. 29-31).

\section{Faculty and Student Success Stories}

I had a number of rewarding experiences in my work as an embedded librarian. I've included a small sample of what I call success stories that demonstrate the importance of offering patrons library services designed with their needs in mind.

A new faculty member asked for a one-on-one training session on the use of the library's electronic resources. His research focused on the leadership traits of school superintendents. We met at his office. I spent two hours helping him to find articles in the library's databases, books, and reports (Shumaker, 2009, p. 239). During the time we worked together, we were able to discuss the library's services that were beneficial for his students. I later facilitated the addition of a number of works in his area of expertise to the library's collection.

Out of these and other contacts, I eventually was asked to teach two instructional sessions for his students. The first session involved the use of the library's resources for research. The second session focused on documenting sources using the new sixth edition of APA format. The library had not previously been involved in providing instruction for the school administration program.

My original assignment to facilitate library services for the doctoral program was fulfilled through discussions with the department chair, director of the program, and the professors teaching courses. A plan was put into place to provide instruction to each cohort of students during the required research methods course taken during the doctoral student's first year in the program. I subsequently taught an instructional session for each of the two cohorts of students.

One professor teaching in the doctoral program forwarded my contact information to his students and posted the information in Blackboard. An announcement of my presence in the College was also included in the department's newsletter 
(-(Ed)evelopments,” 2009, p. 15). As a result, I received many e-mail messages and phone calls from students seeking assistance with literature searches, as well as questions on APA format.

One student whose research interest focused on the educational and social challenges faced by student athletes contacted me several times prior to the due date for a literature review assignment. I made a number of suggestions via e-mail that she utilized leading to the successful completion of her assignment. She sent me a short follow-up message. $-(I)$ just wanted to thank you again for all of your help. I started on my Lit. Review this weekend and was much better prepared with your help and suggestions. Thank you!"

One graduate student met with me on several occasions and maintained an e-mail correspondence as she completed her thesis. She asked for assistance in finding research on vocational education, citing her sources in APA format, and addressing problems in formatting her thesis according to the Graduate School's style guidelines. At the end of the program, she sent me a message.

I fiddled around with the template and got the table of contents right. Then, I defended my thesis on Monday evening and took it straight over to the library for proofreading. ...Thanks so much for all of your help. I could not have done it without you!

One of her professors was generous in her comments.

Last night, two students in my Quantitative Research class told me they met with you recently and that they really appreciated all of the help you gave them in working toward their proposal review of literature. ... both raved about your assistance and felt that the time they spent with you was very productive and helpful. Their comments to me were completely unsolicited, so I wanted you to know that they went out of their way to share the positive feedback with me. As an instructor, I sure appreciate the services you provide. Thanks for your support of our programs!
A final example involves a Liberal Studies faculty member who was working on a proposal for a new course on language acquisition by non-native students speaking English as a second language. There was a very short deadline before the proposal would be considered for approval of the course for the upcoming semester. She needed to gather citations for a bibliography to support the proposal and contacted me for help.

My approach was to do a targeted search in our catalog, the Link+ catalog, and WorldCat for relevant books. I then performed a similar search in ERIC for articles and non-journal literature. Since there were so many results available, I limited my searching to the last five years. I sent out individual e-mail messages organizing the results by the year of publication and including the relevant subject terms from the ERIC thesaurus to facilitate additional searching by the faculty member. Each e-mail message contained an abstract and an attachment with the full text when available. When I checked back to see if the results that I had sent were helpful, I received the following response.

I can't tell you how much this means right now. Your assistance will make it possible for me to meet an impossible timeline. Many LIBS majors would thank you personally if they knew how much you have assisted in making some spring 2010 courses possible. Your work was a terrific help in developing the course proposal.

\section{Conclusion}

In addition to the benefits for faculty and students that come from the utilization of a model of embedded librarianship to provide library services, the library also gained from this experience. A closer relationship was forged with the teaching faculty. The dialogue that ensued afforded an opportunity to communicate how the library was able to meet the research needs of professors, collaborate in the provision of information literacy instruction, and build a library collection that better serves teaching and research (Dewey, 2005, pp. 11-12; Shumaker, 2009, p. 240).

In an age of declining reference statistics, budget cuts and furloughs, and fears that the library is

Education Libraries, Volume 33, Number 2, Winter 2010 
losing its relevance for professors and students, embedded librarianship furnishes library resources and services when and where they are needed by our users (Kesselman \& Watstein, 2009, p. 385). An embedded librarian has the chance to develop an ongoing relationship with a student or faculty member through regular contact in the College. Collaboration with faculty is fostered (Bartnik, 2007, p. 6). The increased utilization of the library for research assistance and instruction enhances its value not only to students and faculty, but also to the decision-makers who determine our budgets (Shumaker, 2009, p. 239).

Often in business, the term - win-win" is used to describe a deal that works well for both parties. Embedded librarianship is a winning proposition not only for the constituents served, but for the librarian who has the opportunity to make a positive difference for students and faculty. If we are willing to step outside the library to serve our patrons when and where we are needed, our value to the processes of teaching, learning, and scholarship will be enhanced.

\section{References}

Bartnik, L. (2007). The embedded academic librarian: The subject specialist moves into the discipline college. Kentucky Libraries, 71(3), 4-9. Retrieved from http://vnweb.hwwilsonweb.com

Bozeman, D., \& Owens, R. (2008). Providing services to online students: Embedded librarians and access to resources. Mississippi Libraries, 72(3), 57-59. Retrieved from http://vnweb.hwwilsonweb.com

California State University, Stanislaus 2008-2009 graduate catalog. (2008a). Turlock, CA: California State University, Stanislaus.

California State University, Stanislaus 2008-2009 undergraduate catalog. (2008b). Turlock, CA: California State University, Stanislaus.

Dewey, B. I. (2005). The embedded librarian: Strategic campus collaborations. Resource
Sharing and Information Networks, 17(1), 517. doi:10.1300/J121v17n01_02

Drumm, M., \& Havens, B. C. (2005). A foot in the door: Experiments with integrating library services into the online classroom. Journal of Library \& Information Services in Distance Learning, 2(3), 25-32.

(Ed)evelopments: Program information. (2009, Spring). (Ed)irections: The Newsletter for the Doctoral Program in Educational Leadership. Retrieved from California State University, Stanislaus, College of Education website: http://www.csustan.edu/EdD/documents/EdDir ectionsR2LoRes.pdf

EDMS 4140: History/social science and visual and performing arts methods. (2009).

Retrieved from California State University, Stanislaus, University Library website: http://library.csustan.edu/wjacobs/Class_pages /EDMS4140.htm

Glynn, T., \& Wu, C. (2003). New roles and opportunities for academic library liaisons: A survey and recommendations. Reference Services Review, 31(2), 122-128. doi:10.1108/00907320310476594

Hall, R. A. (2008). The embedded" librarian in a freshman speech class. College \& Research Libraries News, 69(1), 28-30.

Kesselman, M. A., \& Watstein, S. B. (2009). Creating opportunities: Embedded librarians. Journal of Library Administration, 49(4), 383400. doi:10.1080/01930820902832538

Library class pages. (n.d.). Retrieved from California State University, Stanislaus, University Library website: http://library.csustan.edu:8080/class.htm

Library strategic plan. (2007). Retrieved from California State University, Stanislaus, University Library website: http://library.csustan.edu/general_information/ strategic-plan-2007.pdf 
Matthew, V., \& Schroeder, A. (2006). The embedded librarian program. EDUCAUSE Quarterly, 29(4), 61-65.

Ramsay, K. M., \& Kinnie, J. (2006). The embedded librarian: Getting out there via technology to help students where they learn. Library Journal, 131(6), 34-35.

Shumaker, D. (2009). Who let the librarians out?: Embedded librarianship and the library manager. Reference \& User Services Quarterly, 48(3), 239-242, 257. Retrieved from http://vnweb.hwwilsonweb.com

Smith, S. S., \& Sutton, L. (2008). Embedded librarians: On the road in the Deep South. College \& Research Libraries News, 69(2), 71-74, 85.

Stewart, V. D. (2007). Embedded in the Blackboard jungle: The embedded librarian program at Pulaski Technical College. Arkansas Libraries, 64(3), 29-32. Retrieved from http://vnweb.hwwilsonweb.com
Warren N. Jacobs

California State University, Stanislaus

One University Circle

Turlock, CA 95382

(209) 664-6565

Email: wjacobs@csustan.edu 